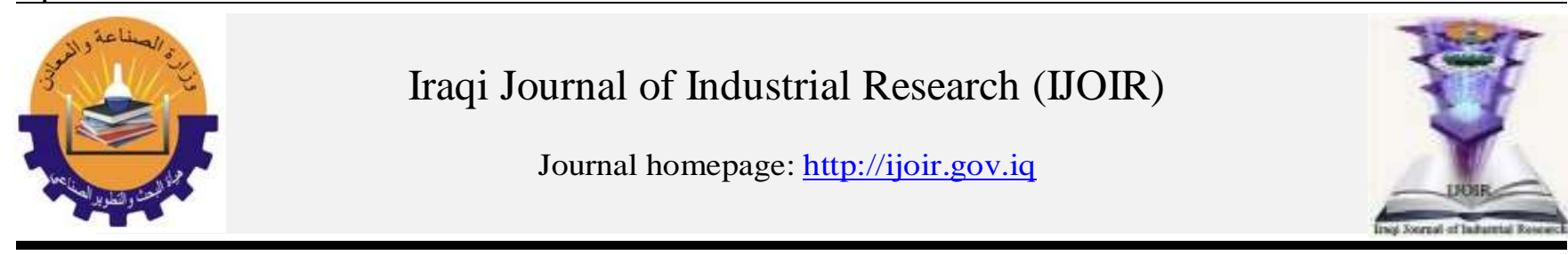

\title{
Improving the Thermal Efficiency of Flat Plate Solar Collector Using Nano-Fluids as a Working Fluids: A Review
}

\author{
Saif Ali Kadhim*, Osama Abd Al-Munaf Ibrahim \\ Mechanical Engineering Department, University of Technology - Iraq
}

\section{Article information}

\section{Article history:}

Received: September, 23, 2021

Accepted: October, 10, 2021

Available online: December, 14, 2021

Keywords:

Solar Energy,

Solar Collector,

Nano-Fluids,

Thermal Efficiency

\section{*Corresponding Author:}

Saif Ali Kadhim

20292@uotechnology.edu.iq

DOI:

https://doi.org/10.53523/ijoirVol8I3ID86

\begin{abstract}
Solar energy is one of the most important types of renewable energy and is characterized by its availability, especially in Iraq. It can be used in many applications, including supply thermal energy by solar collectors. Improving the thermal efficiency of solar collector leads to an increase in the thermal energy supplied. Using a nano-fluid instead of base fluid (water is often used) as a working fluid is a method many used to increase the thermal efficiency of solar collectors. In this article, the latest research that used nano-fluid as a working fluid in evaluating the thermal efficiency of solar collector, type flat plate was reviewed. The thermal efficiency improvement of flat plate solar collector was reviewed based on the type of nanoparticles (metal oxides, semiconductors oxides, carbon compounds) used in the base fluid and comparison was made between these nanoparticles under the same conditions. Moreover, the effect of varying the concentration of nanoparticles in the base fluid and changing the working fluid flow rate on the thermal efficiency of flat plate solar collector was also reviewed. The results of the review showed that nano-fluids containing carbon compounds are better than other nano-fluids and that copper oxide is better than the rest of the metal oxides used in improving the thermal efficiency of flat plate solar collectors.
\end{abstract}

\section{Introduction}

The flat plate solar collector is one of the fixed collector's (it is not tracked to the movement of the sun), which is characterized by simplicity of installation, low cost and requires a little maintenance compared to other types. Flat plate solar collector is used in many applications that require moderate temperatures $\left(100{ }^{\circ} \mathrm{C}\right.$ or less) as it is used in water heating, building heating, and many other uses. Flat plate solar collector consists of an absorber plate with tubes through which a working fluid (heat carrier) passes. The absorber plate is insulated from the bottom and sides and covered from the top with a transparent cover. The working fluid in a flat plate solar collector is usually water; this collector can be used in two systems: Firstly, the open-loop system; this system uses (consumes) the hot water (working fluid) directly that is, it needs to compensate the consumed water. Secondly, the closed-loop system and in this system, it uses (consumes) only the heat energy in the hot water through a heat exchanger that is, the amount of water inside the collector remains constant as in Figure (1) [1]. 
The thermal efficiency of flat plate solar collectors is low compared with tracking solar collectors [1]; so, by using many methods, many researchers have tended to increase the thermal efficiency of a flat plate solar collector. The most prominent and recent of these methods, which is the use of nanoparticles in base fluid (usually water) as working fluid. Using a nano-fluid (nanoparticles + base fluid) as a working fluid that has superior thermal properties improves the efficiency of a flat plate solar collector compared to using water as a working fluid.

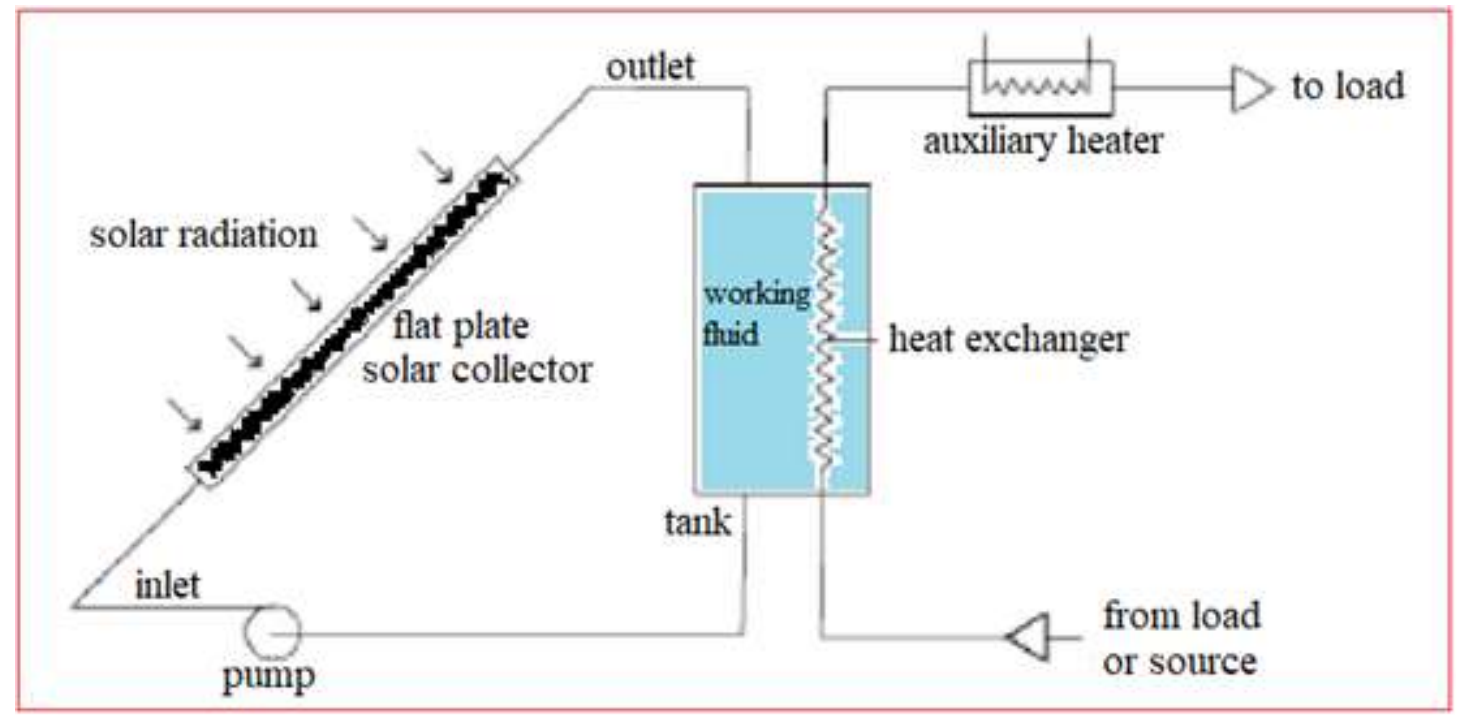

Figure (1). Flat plate solar collector with closed loop system [1].

In this article, the latest research (from 2016 to 2021) in which the thermal efficiency of flat plate solar collector was improved using nano-fluids as a working fluid will be reviewed. This research will be a review based on the nanomaterials used in the base fluid (metal oxides, semiconductor oxides, and carbon compounds), as well as the comparison between those nanomaterials. The effect of nanoparticles concentration in the base fluid and the working fluid flow rate on the thermal efficiency will also be reviewed. This can give the researcher in this field a clear vision for the best nano-fluids and/or fluid flow used in a flat plate solar collector.

It is noteworthy that nano-fluids should be used only in flat plate solar collector with a closed-loop system.

\section{Mathematical Basis}

In this section, the basic mathematical equations used in calculating the thermal efficiency of flat plate solar collector will be presented. Additionally, the specific heat and density of nano-fluid will be stated. Thermal efficiency in the flat plate solar collector is the ratio of useful thermal energy obtained from the collector to incidence solar energy on the collector [2]:

$\eta_{\mathrm{th}}=\frac{\mathrm{Qu}_{\mathrm{u}}}{\mathrm{A}_{\mathrm{c}} \mathrm{G}_{\mathrm{T}}}$

And $Q_{u}=m \cdot C_{p}\left(T_{o}-T_{i}\right)$

where: $\eta_{\text {th }}$ : Thermal efficiency $(\%), Q_{\mathrm{u}}$ : Useful thermal energy $(\mathrm{W}), \mathrm{A}_{\mathrm{c}}$ : Collector area $\left(\mathrm{m}^{2}\right), \mathrm{G}_{\mathrm{T}}$ : Solar radiation $\left(\mathrm{W} / \mathrm{m}^{2}\right), \mathrm{m}:$ Mass flow rate $(\mathrm{kg} / \mathrm{s}), \mathrm{C}_{\mathrm{p}}$ : Specific heat of working fluid $\left(\mathrm{J} / \mathrm{kg}^{\circ} \mathrm{C}\right), \mathrm{T}_{\mathrm{o}}$ : Outlet temperature of working fluid $\left({ }^{\circ} \mathrm{C}\right)$, and $\mathrm{T}_{\mathrm{i}}$ : Inlet temperature of working fluid $\left({ }^{\circ} \mathrm{C}\right)$.

The specific heat and density of nano-fluid is calculated from [3]:

$\mathrm{C}_{\mathrm{p}) \mathrm{nf}}=\frac{\mathrm{C}_{\mathrm{p}) \mathrm{bf}} \rho_{\mathrm{bf}}(1-\varphi)+\mathrm{C}_{\mathrm{p}) \mathrm{np}} \rho_{\mathrm{np}} \varphi}{\rho_{\mathrm{nf}}}$

And $\rho_{\mathrm{nf}}=\rho_{\mathrm{bf}}(1-\varphi)+\rho_{\mathrm{np}} \varphi$ 
where: $\mathrm{C}_{\mathrm{p}) \mathrm{nf}} \& \rho_{\mathrm{nf}}$ : Specific heat $\&$ density of nano-fluid $\left(\mathrm{J} / \mathrm{kg}^{\circ} \mathrm{C}\right), \mathrm{C}_{\mathrm{p}) \mathrm{bf}} \& \rho_{\mathrm{bf}}$ : Specific heat $\&$ density of base fluid $\left(\mathrm{J} / \mathrm{kg}^{\circ} \mathrm{C}\right), \mathrm{C}_{\mathrm{p}) \mathrm{np}} \& \rho_{\mathrm{np}}$ : Specific heat \& density of nanoparticles $\left(\mathrm{J} / \mathrm{kg}^{\circ} \mathrm{C}\right)$, and $\varphi$ : Concentration of nanoparticles (\%), which is defined as the percentage of nanoparticles in the base fluid [4]. It can be a weight percentage or a volumetric percentage.

\section{The Thermo-Physical Properties of Nano-Fluids}

The thermos-physical properties of the nano-fluid such as density, specific heat, thermal conductivity, and viscosity are directly affected by dispersing nanoparticles in the base fluid [5]. In this section, some thermosphysical properties of different types of nano-fluids will be presented.

Increasing the density of working fluid enhances thermal efficiency. Density greatly affects the heat transfer resistance of nano-fluids and directly affecting Reynolds number, Nusselt number, friction factor, and pressure loss. Figure (2) shows the density of some nano-fluids and the effect of nanoparticle concentration on them [6].

Specific heat plays an essential role in the heat transfer and storage processes because low specific heat of nanofluid causes more rise in temperature when exposed to solar energy. Figure (3) shows the specific heat of some nano-fluids and the effect of nanoparticle concentration on them [6].

Increasing the thermal conductivity of the working fluid enhances thermal efficiency. Many factors such as nanoparticles type, nanoparticles shape, nanoparticle size, base fluid type, temperature, and nanoparticles concentration affects the thermal conductivity of nano-fluids [7]. Figure (4) shows the thermal conductivity of some nano-fluids and the effect of nanoparticle concentration on them [6].

Increasing the viscosity of the working fluid will negatively affect the thermal efficiency because the friction factor will be increased. Figure (5) shows the viscosity of some nano-fluids and the effect of nanoparticle concentration on them [6].

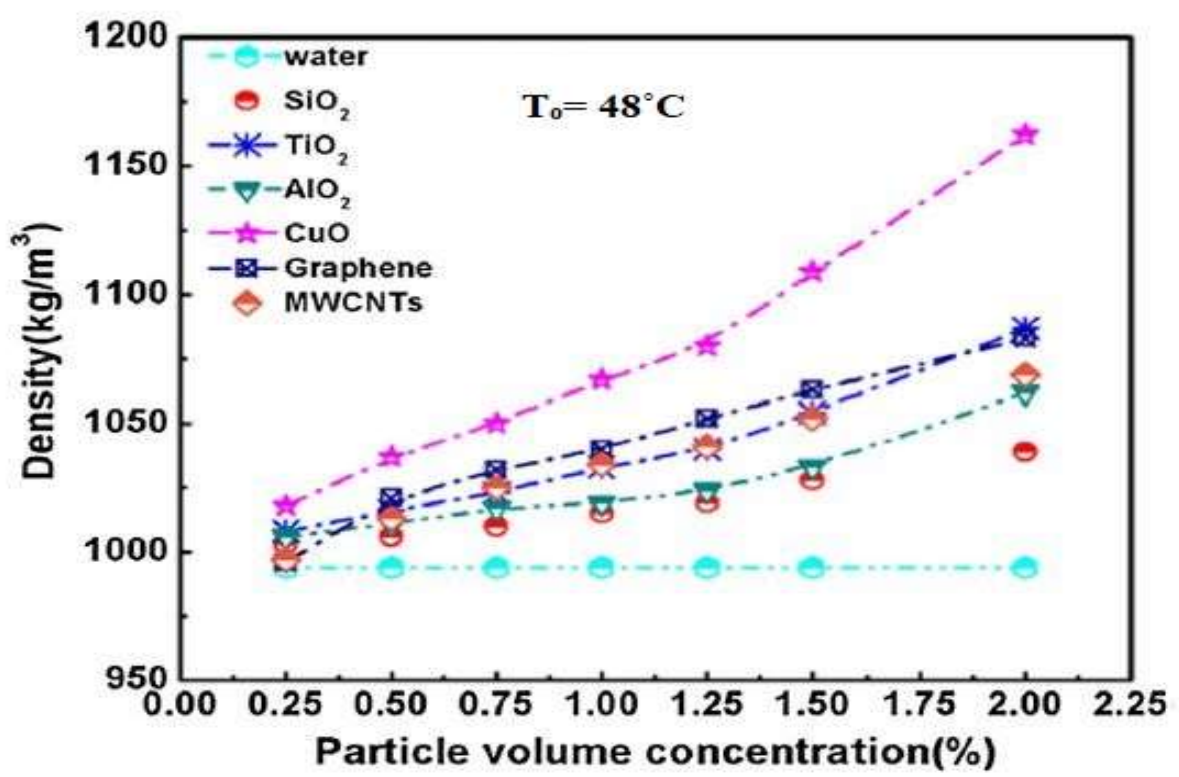

Figure (2). Density of nano-fluids change with volumetric concentration change [6]. 


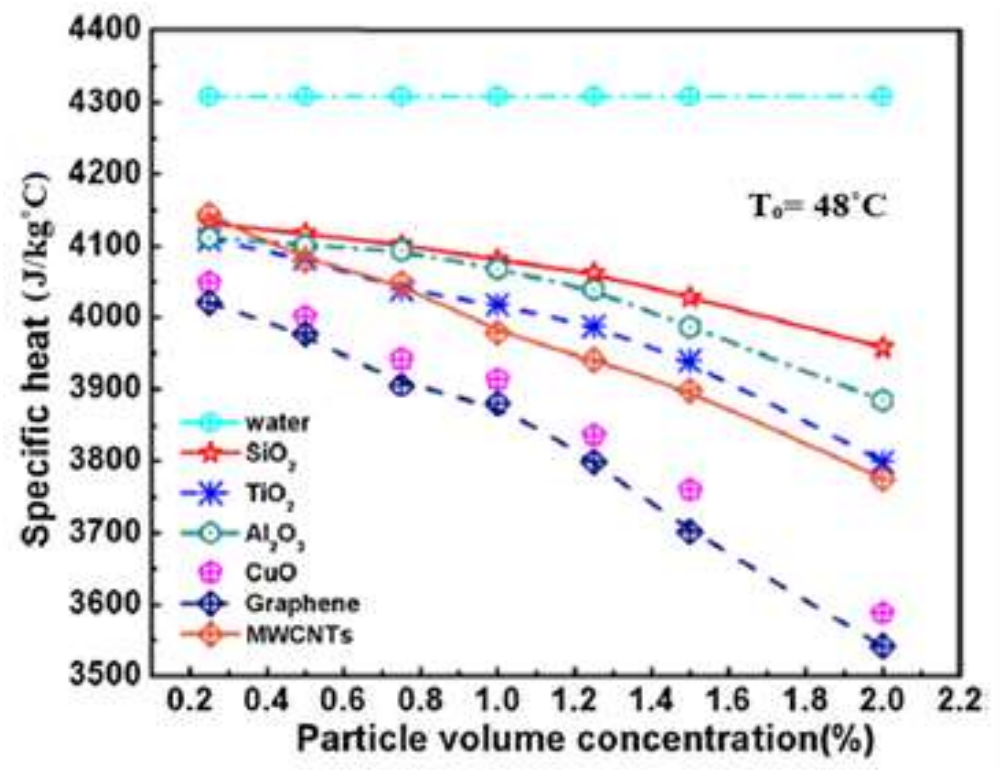

Figure (3). Specific heat of nano-fluids changes with volumetric concentration change [6].

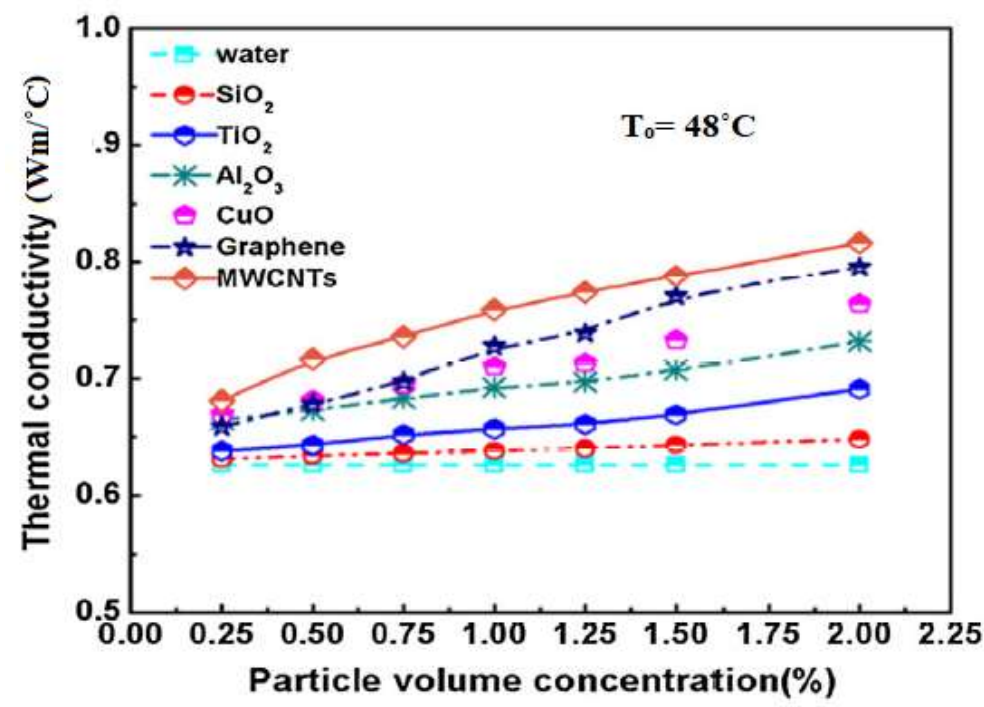

Figure (4). Thermal conductivity of nano-fluids changes with volumetric concentration change [6]. 


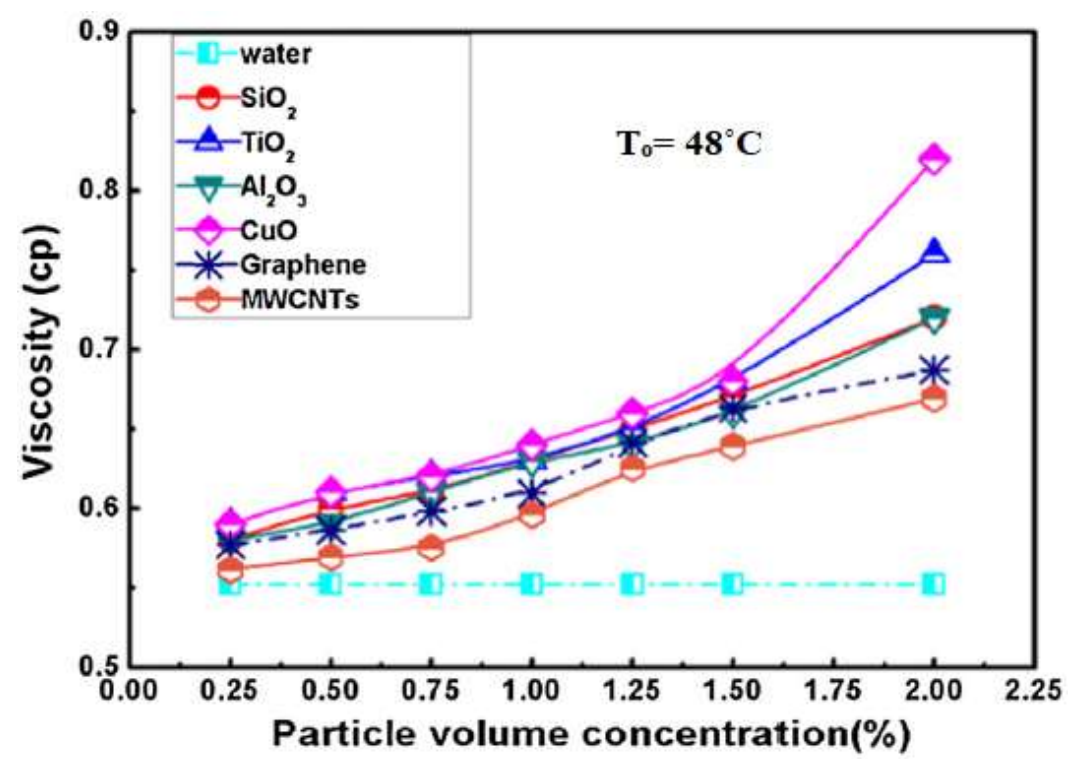

Figure (5). Viscosity of nano-fluids changes with volumetric concentration change [6].

\section{The Use of Nano-Fluids Containing Metal Oxides as Working Fluids}

Many types of metal oxides are used as nanoparticles in the base fluid like aluminum oxide $\left(\mathrm{Al}_{2} \mathrm{O}_{3}\right)$, copper oxide $(\mathrm{CuO})$, zinc oxide $(\mathrm{ZnO})$, iron oxide $\left(\mathrm{Fe}_{3} \mathrm{O}_{4} /\right.$ water $)$, and magnesium oxide $(\mathrm{MgO})$.

Janusz T. Cieśliński et al. (2016) [8] used a nano-fluid consisting of aluminum oxides in water $\left(\mathrm{Al}_{2} \mathrm{O}_{3} /\right.$ water $)$ with volume concentrations $(0.1 \%, 0.2 \%$, and $0.4 \%)$ in addition to water as working fluids in a flat plate solar collector. Experimentally tested flat plate solar collector at flow rates of $(1,2$, and $2.831 / \mathrm{min})$. The results showed that the thermal efficiency of flat plate solar collector increases when using nano-fluid compared to the result when using water; the best increase was when a nano-fluid with a concentration of $0.2 \%$ and a flow rate of $21 / \mathrm{min}$ were used.

Abbas Sahi Shareef et al. (2016) [9] they used a nano-fluid consisting of aluminum oxides in water $\left(\mathrm{Al}_{2} \mathrm{O}_{3} / \mathrm{water}\right)$ with two a volume concentration $(0.1 \%$ and $0.2 \%)$ in addition to water as working fluids in a flat plate solar collector. Experimentally tested flat plate solar collector at flow rates of $(1,1.6$, and $2 \mathrm{l} / \mathrm{min})$. The results showed a remarkable improvement in the thermal efficiency when using nano-fluid compared to water in a flat plate solar collector, especially when using nano-fluid with a $0.5 \%$ concentration and a $21 / \mathrm{min}$ flow rate.

Sahil Arora and Sudhakar Subudhi (2017) [10] used a nano-fluid consisting of aluminum oxides in water $\left(\mathrm{Al}_{2} \mathrm{O}_{3} /\right.$ water $)$ with a volume concentration $(0.1 \%)$ as working fluids - in addition to water - in a flat plate solar collector. Experimentally tested flat plate solar collector at flow rates $(1,2,3,4$, and 5 1/min). The results showed a remarkable increase in the thermal efficiency of flat plate solar collector when using nano-fluid compared to the result when usingwater. The best increase was $23.76 \%$ at a flow of $31 / \mathrm{min}$.

A.A. Hawwash et al. (2018) [11] they presented an experimental and numerical study to examine a flat plate solar collector's performance using water and aluminum oxide $\left(\mathrm{Al}_{2} \mathrm{O}_{3} /\right.$ water $)$ with different volume concentrations as working fluids. Experimental results showed an improvement in the thermal efficiency of flat plate solar collector from $3 \%$ to $18 \%$ when using nano-fluid compared to water, while the numerical results showed that an excessive increase in the concentration of aluminum oxide in water leads to negative results.

Mohsen Mirzaei (2019) [12] used a nano-fluid consisting of copper oxides in water $(\mathrm{CuO} /$ water) with a volume concentration of $0.1 \%$ and water as working fluids in a flat plate solar collector. Experimentally tested flat plate solar collector on more than one flow rate in which the results showed that the thermal efficiency of flat plate solar collector has increased when a nano-fluid was used compared to using water as follows: $15.2 \%, 17.1 \%$, and $25.1 \%$ at flow rates 1,2 , and $41 /$ min respectively. 
Nitesh Singh Rajput et al. (2019) [13] used a nano-fluid consisting of aluminum oxides in water $\left(\mathrm{Al}_{2} \mathrm{O}_{3} / \mathrm{water}\right)$ with volume concentrations $(0.1 \%, 0.2 \%$, and $0.3 \%)$ in addition to water as working fluids in a flat plate solar collector. Experimentally tested flat plate solar collector at flow rates $(1,2$, and $31 / \mathrm{min})$ showed a remarkable increase in the thermal efficiency of flat plate solar collector when using nano-fluid compared to water. The best increase was $21.32 \%$ at a concentration of $0.3 \%$ and a flow of $31 / \mathrm{min}$.

Mousa M. Mohamed et al. (2020) [14] they used water and a nano-fluid consisting of zinc oxides in water $(\mathrm{ZnO} /$ water) at two volume concentrations $(0.05 \%$ and $0.1 \%)$ as working fluids in a flat plate solar collector used with a thermal storage system. The experimental results showed an increase in the thermal efficiency of flat plate solar collector when using the nano-fluid compared to water as follows: $4.81 \%$ and $6.57 \%$ at a concentration of $0.05 \%$ and $0.1 \%$, respectively.

Shubham Sharma et al. (2020) [15] they presented an experimental study to evaluate a flat plate solar collector performance. They used water and copper oxide in water $(\mathrm{CuO} /$ water) with a range of volume concentrations $(0.25 \%-2 \%)$ as working fluids. The results compared the thermal efficiency with a nano-fluid and the thermal efficiency with water; the thermal efficiency with a nano-fluid was higher than that with water, and the highest thermal efficiency recorded was $57.1 \%$ at a concentration of $1.5 \%$ and a flow of $0.03 \mathrm{~kg} / \mathrm{s}$.

Nang Khin Chaw Sint et al. (2020) [16] ran a simulation using MATLAB software to verify the perfect concentration of a nano-fluid ( $\mathrm{CuO} /$ water) to be used in a flat plate solar collector as a working fluid. Their results showed that the maximum thermal efficiency was obtained at a volume concentration of $0.5 \%$ and a flow rate of $1 \mathrm{l} / \mathrm{min}$. They also compared the nano-fluid to water and found that the thermal efficiency increased by $4.78 \%$ when using $(\mathrm{CuO} /$ water $)$.

Suraj Choudhary et al. (2021) [17] used a nano-fluid consisting of magnesium oxides in water (MgO/water) with two volume concentrations $(0.1 \%$ and $0.3 \%)$ as working fluids in a flat plate solar collector. Experimentally tested flat plate solar collector at flow rates $(0.5,1$, and $1.5 \mathrm{l} / \mathrm{min})$ showed that the best performance was when a nanofluid of $0.3 \%$ concentration and $1 \mathrm{l} / \mathrm{min}$ flow was used.

\section{The Use of Nano-Fluids Containing Metal Oxides as Working Fluids}

Many types of semiconductor oxides are used as nanoparticles in the base fluid like silicon oxide $\left(\mathrm{SiO}_{2} /\right.$ water), titanium oxide $\left(\mathrm{TiO}_{2} /\right.$ water $)$, cerium oxide $\left(\mathrm{CeO}_{2} /\right.$ water $)$, and tungsten oxide $\left(\mathrm{WO}_{3} /\right.$ water $)$.

A R. Noghrehabadi et al. (2016) [18] used a nano-fluid consisting of silicon oxide in water $\left(\mathrm{SiO}_{2} /\right.$ water) with a weight concentration $(1 \%)$ in addition to water as working fluids in a flat plate solar collector. Experimentally tested flat plate solar collector at different flow rates showed a slight increase in the thermal efficiency of flat plate solar collector when using nano-fluid compared to water, it was $2.1 \%$ at a flow of $1.41 / \mathrm{min}$.

Ammar Maouassi et al. (2017) [19] presented a numerical study to investigate the performance of a flat solar collector using $\left(\mathrm{SiO}_{2} /\right.$ water $)$ as a working fluid and compare its performance when using water as a working fluid. They chose volume concentrations that rangined from $1 \%$ to $10 \%$, and with several flow rates when tested. The results showed that increasing the concentration of $\mathrm{SiO}_{2}$ nanoparticles in water improves the performance of the flat plate solar collector, especially at high flow rates.

M.A. Sharafeldin and Gyula Gróf (2018) [20] used a nano-fluid consisting of cerium oxides in water $\left(\mathrm{CeO}_{2} /\right.$ water $^{2}$ with volume concentrations of $(0.0167 \%, 0.0333 \%$, and $0.0666 \%)$ in addition to water as working fluids in a flat plate solar collector. Experimentally tested flat plate solar collector at flow rates $(0.015,0.018$ and $0.019 \mathrm{~kg} / \mathrm{s} \mathrm{m} 2)$. Their results showed an increase in the thermal efficiency of flat plate solar collector when using nano-fluid compared to water, and the best increase was $10.74 \%$ at a concentration of $0.0666 \%$ and a flow of $0.019 \mathrm{~kg} / \mathrm{s} \mathrm{m}^{2}$.

J. Vinoth Kumar et al. (2021) [21] they used a nano-fluid consisting of tungsten oxide in water (WO3/water) with a volume concentration of $(0.0167 \%, 0.0334 \%$ and $0.0667 \%)$ in addition to water as working fluids in a flat plate solar collector. Experimentally tested flat plate solar collector at constant flow rate results showed an improvement 
in the thermal efficiency of flat plate solar collector when using the nano-fluid compared to water, especially when using the nano-fluid with a concentration of $0.0667 \%$.

\section{The Use of Nano-Fluids Containing Carbon Compounds as Working Fluids}

Omer A Alawi et al. (2020) [22] used a nano-fluid consists of pentaethylene glycol-thermally treated graphenewater with weight concentrations $(0.025 \%, 0.05 \%, 0.075 \%$, and $0.1 \%)$ in addition to water as working fluids in a flat plate solar collector. The results of experimentally tested flat plate solar collector at different flow rates showed an increase in the thermal efficiency of flat plate solar collector when using nano-fluid compared to using water, and the best increase was $10.74 \%$ at a concentration of $0.0666 \%$ and a flow of $0.019 \mathrm{~kg} / \mathrm{s} \mathrm{m} 2$. The results showed an increase in the thermal efficiency of flat plate solar collector when using nano-fluid compared to water, and the best increase at a concentration of $0.1 \%$ and as follows: $10.6 \%, 11.1 \%$, and $13.1 \%$ at a flow rate of $0.00833 \mathrm{~kg} / \mathrm{s}$, $0.01667 \mathrm{~kg} / \mathrm{s}$, and $0.025 \mathrm{~kg} / \mathrm{s}$.

Omar Mohammed Hamdoon (2020) [23] presented a numerical study to improving the performance of a flat plate solar collector using (Multi-Wall Carbon Nano Tube-Water) MWCNT- $\mathrm{H}_{2} \mathrm{O}$ as a working fluid and compared its performance to the performance when using water. Various concentrations ranging from $0 \%$ to $6 \%$ were selected, as well as, varying the flow rates from $0.004 \mathrm{~kg} / \mathrm{s}$ to $0.03 \mathrm{~kg} / \mathrm{s}$ were tested. The results showed an increase in the thermal efficiency of flat plate solar collector when using nano-fluid compared to water, and this increase ranged from $2.41 \%$ to $2.91 \%$ at $0.004 \mathrm{~kg} / \mathrm{s}$ from $4.67 \%$ to $6.68 \%$ at $0.03 \mathrm{~kg} / \mathrm{s}$.

L. Syam Sundar et al. (2020) [24] used a nano-fluid consisting of nanodiamond particles in water (DN/water) with volume concentrations $(0.2 \%, 0.4 \%, 0.6 \%, 0.8 \%$, and $1 \%)$ in addition to water as working fluids in a flat plate solar collector. The results showed that when using water, the thermal efficiency reached $53 \%$, while when using nano-fluid at a concentration of $1 \%$, the efficiency reached $74 \%$, and this is the best improvement.

Omer A Alawi et al. (2021) [25] presented an experimentally and theoretically study of covalently functionalized graphene $(\mathrm{Gr})$ suspended in distilled water with different weight concentrations $(0.025 \%, 0.05 \%, 0.075 \%$, and $0.1 \%$ ) as working fluid inside a flat plate solar collector. The comparison was also made when using water as a working fluid. It was tested experimentally and theoretically at flow rates $(0.5,1$, and $1.5 \mathrm{~kg} / \mathrm{min})$. The results showed an increase in the thermal efficiency of flat plate solar collector when using nano-fluid compared to water, and the best increase was $13 \%$ at the highest concentration and flow rate.

L. Harish Kumar et al. (2021) [26] presented an investigation about the effects of using eco-friendly, noncorrosive, covalently functionalized Graphene nanoplatelets with gallic acid (GGNPs) as working fluid inside a flat plate solar collector. A nano-fluid consists of (GGNPs/water) with a weight concentrations $(0.025 \%, 0.05 \%$, $0.075 \%$ and $0.1 \%)$. It was experimentally tested at flow rates $(0.5,1$, and $1.5 \mathrm{~kg} / \mathrm{min})$, and the comparison was made when using water as a working fluid. The results they had was that the maximum enhancement in the thermal efficiency of flat plate solar collector was $24.09 \%$ compared to the one with water at a concentration of $0.1 \%$ and a flow rate of $1.5 \mathrm{l} / \mathrm{min}$.

\section{Comparison of Nano-Fluids Based on The Type of Nanoparticles Used}

Marjan B. Nejad et al. (2017) [27] presented a numerical study to investigate in performance a flat plate solar collector used different nano-fluids including (MWCNT- $\mathrm{H}_{2} \mathrm{O}$ and $\mathrm{Al}_{2} \mathrm{O}_{3} /$ water) in addition to water as working fluids. Different weight concentrations ranging (1-2\%) were selected and tested on flow rates ranging $(0.05-0.6$ $1 / \mathrm{min})$. The results showed an increase in the thermal efficiency of flat plate solar collector when using nano-fluids compared to water, and the thermal efficiency of $\mathrm{MWCNT}-\mathrm{H}_{2} \mathrm{O}$ was greater than the thermal efficiency of $\mathrm{Al}_{2} \mathrm{O}_{3} /$ water.

Sujit Kumar Verma et al. (2017) [6] prepared several nano-fluids consisting of carbon compounds, metal oxides, and semiconductor oxides in water as follows: (MWCNTs- $\mathrm{H}_{2} \mathrm{O}, \mathrm{Gr} /$ water, $\mathrm{CuO} /$ water, $\mathrm{Al}_{2} \mathrm{O}_{3} / \mathrm{water} \mathrm{TiO}_{2} /$ water, and $\mathrm{SiO}_{2}$ /water). These nano-fluids, in addition to water, were used as working fluids in the evaluation of a flat plate solar collector. Experimental tested was with a volume concentrations $(0.25 \%, 0.5 \%, 0.75 \%, 1 \%, 1.25 \%$, $1.5 \%, 1.75 \%$ and $2 \%$ ) and a flow rates ranging from $0.01 \mathrm{~kg} / \mathrm{s}$ to $0.05 \mathrm{~kg} / \mathrm{s}$. The results showed an increase in the thermal efficiency of flat plate solar collector when using nano-fluids compared to water, especially between the 
concentrations $0.75 \%-1 \%$ and the flow rates $0.03 \mathrm{~kg} / \mathrm{s}-0.035 \mathrm{~kg} / \mathrm{s}$. The best results were recorded for an increase in the thermal efficiency of flat plate solar collector with a concentration of $0.75 \%$ and a flow rate of $0.03 \mathrm{~kg} / \mathrm{s}$ as

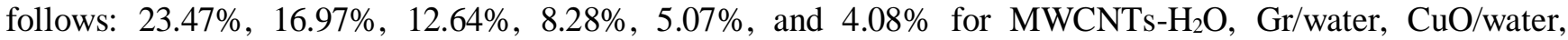
$\mathrm{Al}_{2} \mathrm{O}_{3} /$ water, $\mathrm{TiO}_{2} /$ water, and $\mathrm{SiO}_{2} /$ water, respectively as shown in Figure (6).

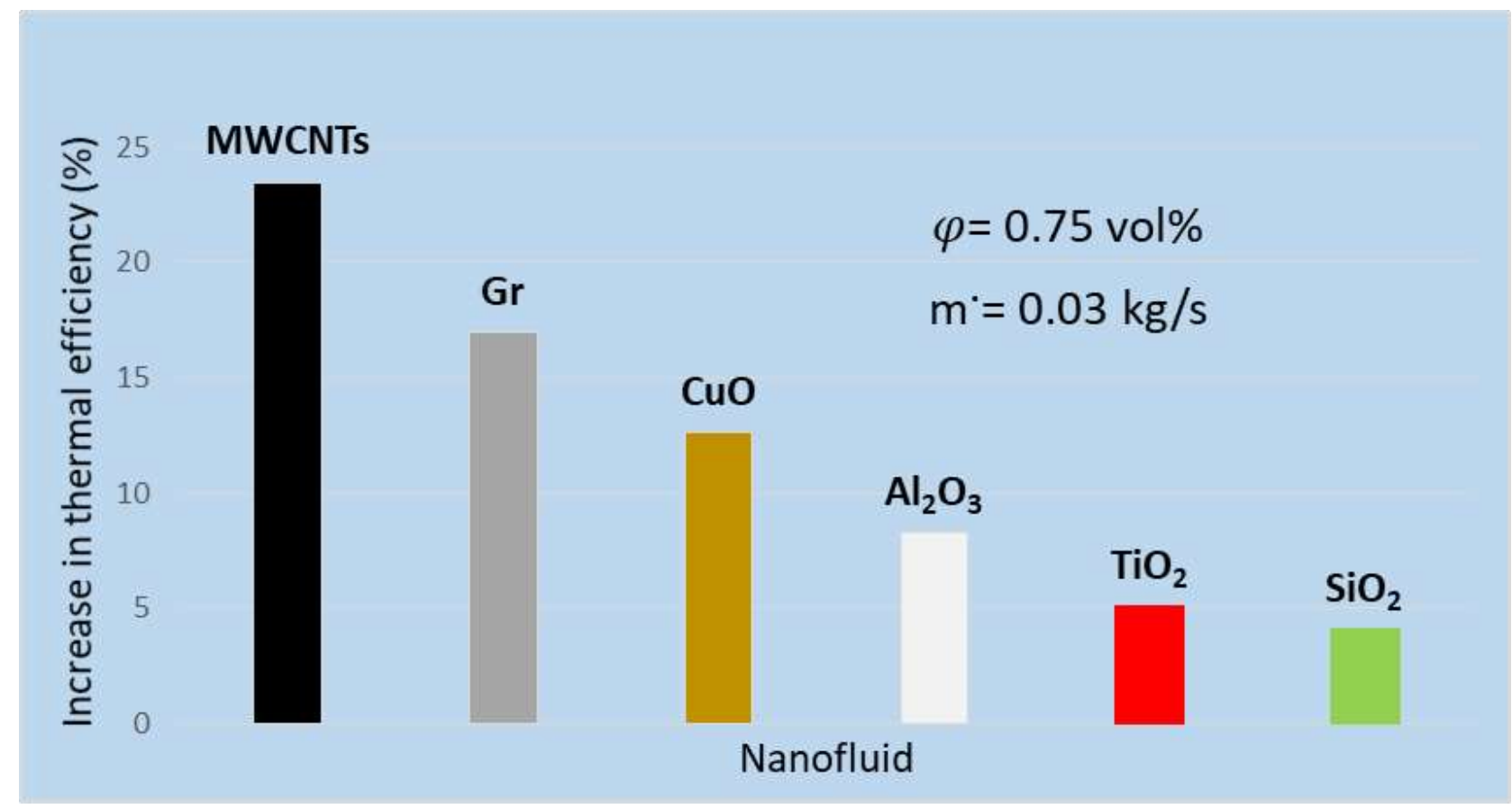

Figure (6). Improvement in thermal efficiency using nano-fluids [6].

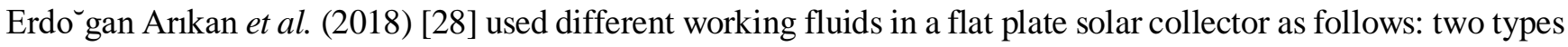
of nano-fluids $\left(\mathrm{Al}_{2} \mathrm{O}_{3} /\right.$ water) and ( $\mathrm{ZnO} /$ water) with and without ethylene glycol (EG) in addition to water. A weight concentration in water of $0.25 \%$ oxides and $25 \%$ ethylene glycol was used, and it was experimentally tested with flow rates $(0.05,0.07$, and $0.09 \mathrm{~kg} / \mathrm{s})$. The results showed an increase in the thermal efficiency of flat plate solar collector when using nano-fluids compared to water, especially when adding ethylene glycol, and the best increase was $(15.13 \%)$ for $\left(\mathrm{Al}_{2} \mathrm{O}_{3} /\right.$ water $)$ with ethylene glycol at a flow rate of $0.09 \mathrm{~kg} / \mathrm{s}$.

Yijie Tong et al. (2020) [29] presented an experimental comparison between several working fluids in a flat plate solar collector, where they used water and (MWCNT/water, $\mathrm{CuO} /$ water, $\mathrm{Al}_{2} \mathrm{O}_{3} /$ water, $\mathrm{Fe}_{3} \mathrm{O}_{4} /$ water); and for each nano-fluid, they used multiple concentrations close to its ideal concentration. Tested a flat plate solar collector with different flow rates. The results showed that the maximum thermal efficiency was $87 \%$ when using MWCNT/water. Also, increasing the flow rate improves the thermal efficiency, and the best improvement was when using MWCNT/water, as shown in Figure (7). 


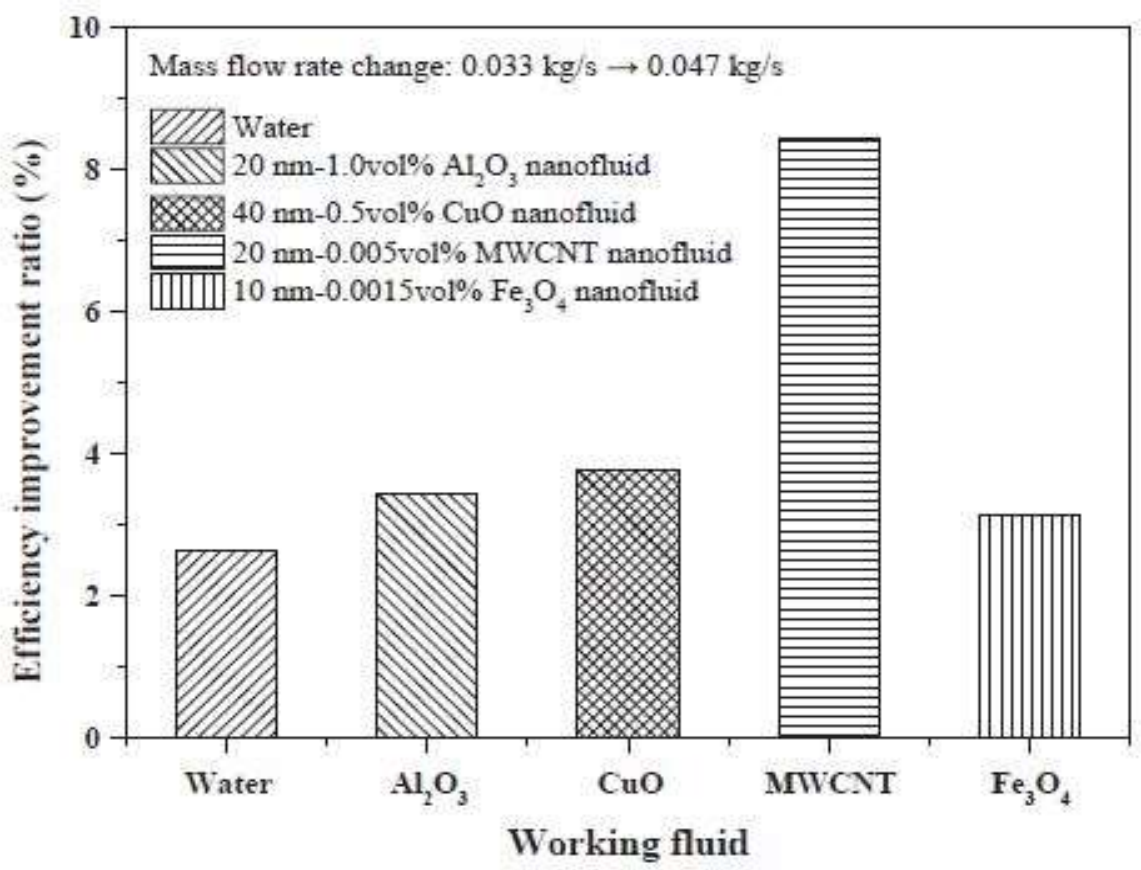

Figure (7). Improvement in thermal efficiency when changing flow rates for different types of working fluids [29].

M. S. Gad and Mokhtar Said (2021) [30] used water and nanoparticles of aluminum oxides $\mathrm{Al}_{2} \mathrm{O}_{3}$ and titanium oxides $\mathrm{TiO}_{2}$ at a concentration of $2 \%$ by weight in water as working fluids in a flat plate solar collector. It was experimentally tested at flow rates $(2,4$, and $61 / \mathrm{min})$. The results showed that the thermal efficiency of flat plate solar collector was as follows $\left(\mathrm{TiO}_{2} /\right.$ water $>\mathrm{Al}_{2} \mathrm{O}_{3} /$ water $>$ water) at all flow rates and the maximum increase in thermal efficiency was $30 \%$ for $\mathrm{TiO}_{2} /$ water and $22 \%$ for the $\mathrm{Al}_{2} \mathrm{O}_{3} /$ water compared to water, also the best flow rate was $21 / \mathrm{min}$.

A.A. Hawwash et al. (2021) [31] designed a mathematical model (CFD) to study the performance of a flat plate solar collector used aluminum oxide $\mathrm{Al}_{2} \mathrm{O}_{3}$ and copper oxide $\mathrm{CuO}$ in water as working fluids with different concentrations from $0.1 \%$ to $2 \%$. The validity of the mathematical model was confirmed by comparison with experimental results. The results showed that the best performance is when using $\mathrm{CuO} /$ water at a concentration of $0.5 \%$ and the activity of $\mathrm{CuO} /$ water is better than that of $\mathrm{Al}_{2} \mathrm{O}_{3} /$ water under the same conditions.

R. M. Mostafizur et al. (2021) [32] used four types of nano-fluids, all from oxides of solid materials in water $\left(\mathrm{CuO} /\right.$ water, $\mathrm{Al}_{2} \mathrm{O}_{3} /$ water, $\mathrm{TiO}_{2} /$ water, and $\mathrm{MgO} /$ water $)$ in addition to water as working fluids in the flat plate solar collector with volume concentrations (1-4\%). Theoretically tested with a flow rate (1-4 1/min), the results showed an increase in the thermal efficiency of flat plate solar collector when using nano-fluids compared to water as shown in Figure (8), and that the largest thermal efficiency values were at a volume concentration of $2 \%$ and a flow of $3.91 / \mathrm{min}$ and as follows: $38.21 \%, 35.32 \%, 34.77 \%, 34.17 \%$ and $31 \%$ for $\mathrm{CuO} / \mathrm{water}, \mathrm{Al}_{2} \mathrm{O}_{3} /$ water, $\mathrm{MgO} /$ water, $\mathrm{TiO}_{2} /$ water, and water, respectively. 


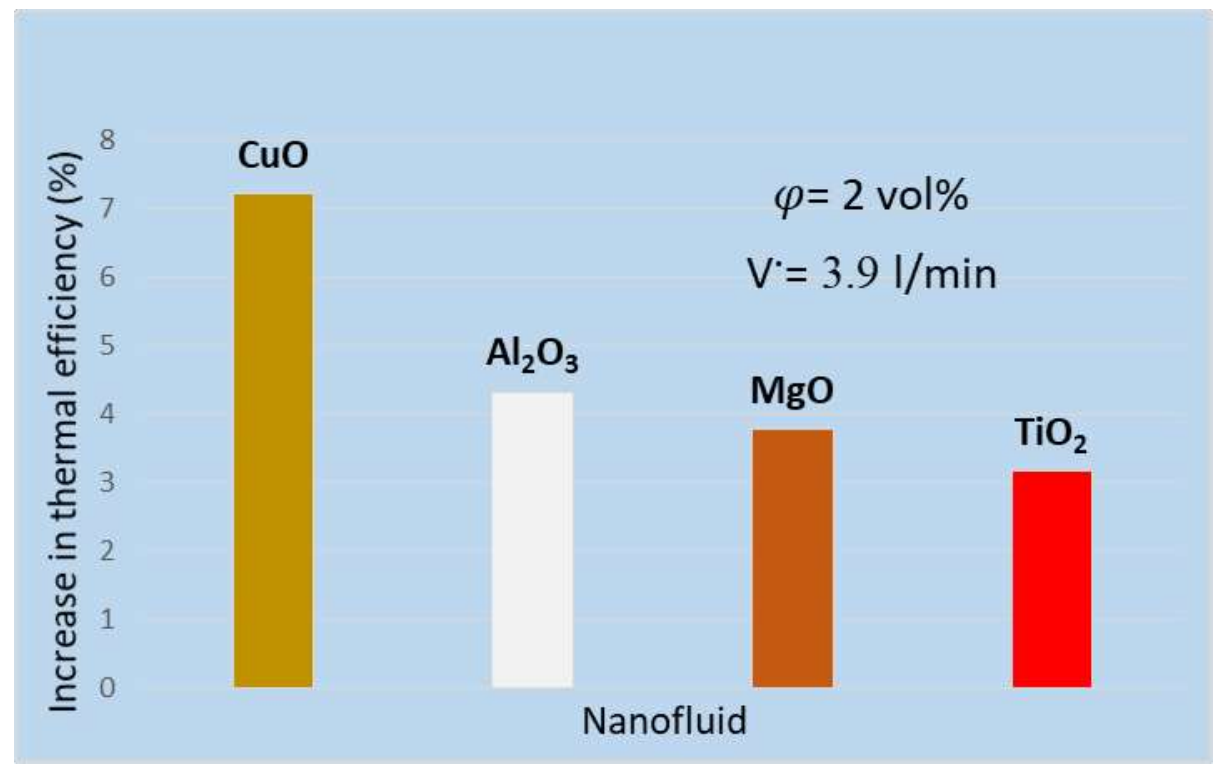

Figure (8). Improvement in thermal efficiency using nano-fluids. [32]

Naveed Akram et al. (2021) [33] presented an experimental study to investigate in performance of a flat plate solar collector used different nano-fluids (f-GNP is carbon compound, $\mathrm{ZnO}$ /water, and $\mathrm{SiO}_{2} /$ water) in addition to water as working fluids. The nano-fluids used were $0.1 \%$ by weight, and the experimental test was carried out at flow rates $(0.8,1.2$, and $1.6 \mathrm{~kg} / \mathrm{min})$. The results showed an increase in the thermal efficiency of flat plate solar collector when using nano-fluids compared to water, and the best increase was at $1.6 \mathrm{~kg} / \mathrm{min}$ and as follows: $17.45 \%$ for $\mathrm{f}$ GNP, $13.05 \%$ for $\mathrm{ZnO} /$ water, and $12.36 \%$ for $\mathrm{SiO}_{2} /$ water as shown in Figure (9).

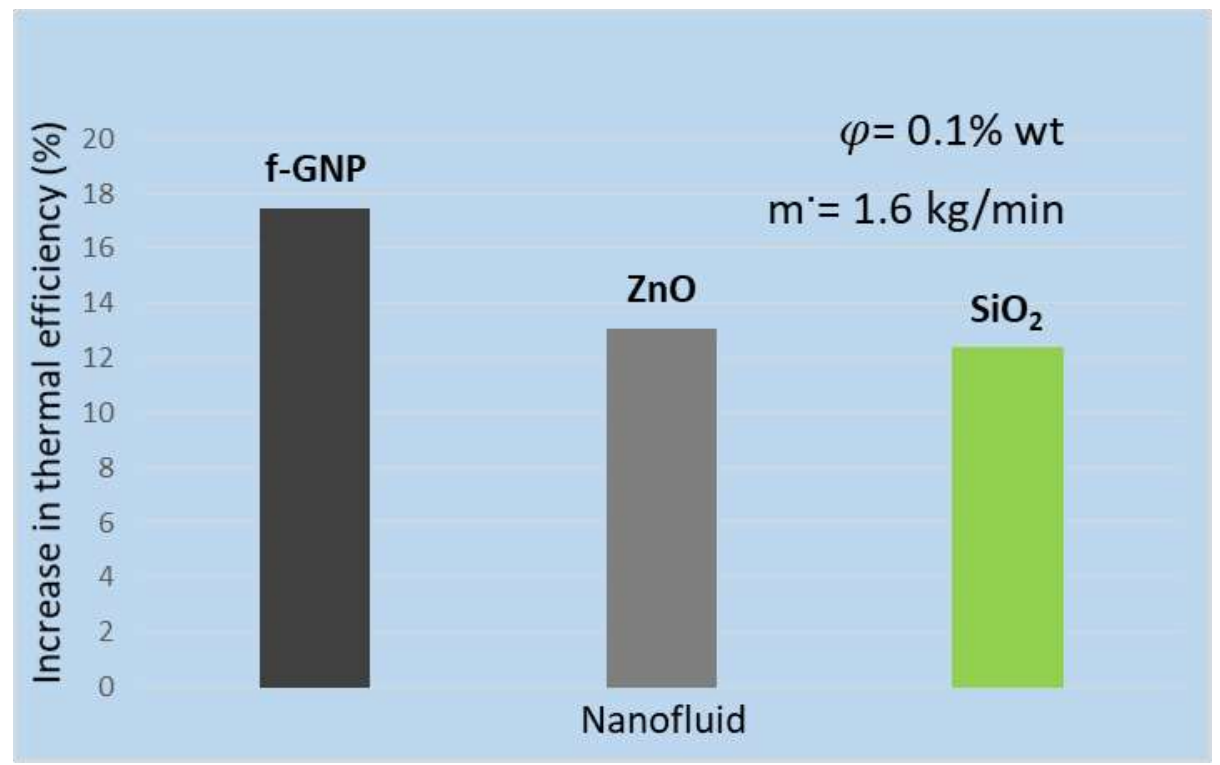

Figure (9). Improvement in thermal efficiency using nano-fluids. [33]

\section{Conclusions}

From the articles presented, we concluded that using nano-fluids improve the the efficiency of flat plate solar collector compared to using water, and that the best nano-fluids that improve the thermal efficiency of flat plate solar collector are the ones using carbon compounds in the first place, then metal oxides, and finally the semiconductor oxides. When comparing the nano-fluids that use metal oxides, it was concluded that the best nanofluid that improves the thermal efficiency of flat plate solar collector is the copper oxide $\mathrm{CuO} /$ water. It was also concluded that increasing the flow rate of the working fluid within certain limits leads to an increase in thermal efficiency of the flat plate solar collector as an excessive increase brings negative results because the difference between the outlet and inlet temperature of the flat plate solar collector will decrease. It is well known that each 
nano-fluid has ideal concentrations that differ from any other nano-fluid; low concentrations of nanoparticles in a base fluid may not improve thermal efficiency significantly, and an excessive increase in the concentration of nanoparticles in a base fluid may lead to negative results due to the high viscosity of the nano-fluid and agglomeration of nanoparticles, which leads to a decrease in the heat transfer process.

It is worth mentioning, there are nano-fluids based on other materials that have not been addressed, including metal nanoparticles like copper, aluminum, and silver $[34,35]$ also hybrid nanoparticles (mixing two or more types of nanoparticles) $[36,37]$. We recommend researchers in this field to see it.

\section{Reference}

[1] J. A. Duffie and W. A. Beckman, "Selected heat transfer topics," Sol. Eng. Therm. Process. 4th ed.; John Wiley \& Sons Inc. Hoboken, NJ, USA, pp. 138-172, 2013.

[2] Q. J. Abdul-Ghafou, A. A. Mohammed, and S. A. Kadhim, "Evaluation of the effect of dusty weather on the performance of flat plate solar collector," Adv. Nat. Appl. Sci., vol. 10, no. 13, pp. 125-131, 2016.

[3] Y. Xuan and W. Roetzel, "Conceptions for heat transfer correlation of nanofluids," Int. J. Heat Mass Transf., vol. 43, no. 19, pp. 3701-3707, 2000.

[4] A. H. Askar, S. A. Kadhim, and S. H. Mshehid, "The surfactants effect on the heat transfer enhancement and stability of nanofluid at constant wall temperature," Heliyon, vol. 6, no. 7, p. e04419, 2020.

[5] S. A. Angayarkanni and J. Philip, "Review on thermal properties of nanofluids: Recent developments," Adv. Colloid Interface Sci., vol. 225, pp. 146-176, 2015.

[6] S. K. Verma, A. K. Tiwari, and D. S. Chauhan, "Experimental evaluation of flat plate solar collector using nanofluids," Energy Convers. Manag., vol. 134, pp. 103-115, 2017.

[7] T. B. Gorji and A. A. Ranjbar, "A review on optical properties and application of nanofluids in direct absorption solar collectors (DASCs),” Renew. Sustain. Energy Rev., vol. 72, pp. 10-32, 2017.

[8] J. T. Cieśliński, B. Dawidowicz, and A. Popakul, "Performance of the flat plate solar collector operated with water- $\mathrm{Al}_{2} \mathrm{O}_{3}$ nanofluid," in Applied Mechanics and Materials, 2016, vol. 831, pp. 181-187.

[9] A. S. Shareef, M. H. Abbod, and S. Q. Kadhim, "Experimental investigation for flow rate effect on a flat plate solar collector with the using of Al2O3 nanofluids as a heat transfer fluid," Int J Mech Mechatronics Eng, vol. 16, pp. 42-48, 2016.

[10] S. Arora and S. Subudhi, "Experimental Study of Performance of Slotted Solar Flat Plate Collector Using Nano-fluids and Water," Proceedings of the $44^{\text {th }}$ National Conference on Fluid Mechanics and Fluid Power, p. $1-5,14-16 / 12 / 2017$.

[11] A. A. Hawwash, A. K. A. Rahman, S. A. Nada, and S. Ookawara, "Numerical investigation and experimental verification of performance enhancement of flat plate solar collector using nanofluids," Appl. Therm. Eng., vol. 130, pp. 363-374, 2018.

[12] M. Mirzaei, "Experimental investigation of $\mathrm{CuO}$ nanofluid in the thermal characteristics of a flat plate solar collector," Environ. Prog. I\& Sustain. Energy, vol. 38, no. 1, pp. 260-267, 2019.

[13] N. S. Rajput, D. D. Shukla, D. Rajput, and S. K. Sharm, "Performance analysis of flat plate solar collector using $\mathrm{Al}_{2} \mathrm{O}_{3}$ /distilled water nanofluid: an experimental investigation," Mater. Today Proc., vol. 10, pp. 52-59, 2019.

[14] M. M. Mohamed, N. H. Mahmoud, and M. A. Farahat, "Energy storage system with flat plate solar collector and water-ZnO nanofluid," Sol. Energy, vol. 202, pp. 25-31, 2020.

[15] S. Sharma, S. Tiwari, A. K. Tiwari, G. Nandan, and R. Prakash, "Thermal Performance Enhancement of FlatPlate Solar Collector Using $\mathrm{CeO}_{2}-$-Water Nanofluid," in Advances in Solar Power Generation and Energy Harvesting, Springer, Singapore, 2020, pp. 109-118.

[16] N. K. C. Sint, I. A. Choudhury, and H. H. Masjuki, "Optimum Utilisation of CuO Nanofluid in Flat Plate Solar Collector,” Int. J. Automot. Mech. Eng., vol. 17, no. 4, pp. 8384-8396, 2020.

[17] S. Choudhary, A. Sachdeva, and P. Kumar, "Time-based assessment of thermal performance of flat plate solar collector using magnesium oxide nanofluid," Int. J. Sustain. Energy, vol. 40, no. 5, pp. 460-476, 2021.

[18] A. Noghrehabadi, E. Hajidavalloo, and M. Moravej, "Experimental investigation of efficiency of square flatplate solar collector using $\mathrm{SiO}_{2}$ /water nanofluid," Case Stud. Therm. Eng., vol. 8, pp. 378-386, 2016.

[19] A. Maouassi, A. Baghidja, S. Daoud, and N. Zeraibi, "Numerical study of nanofluid heat transfer $\mathrm{SiO}_{2}$ through a solar flat plate collector," Int. J. Heat Technol., vol. 35, no. 3, pp. 619-625, 2017.

[20] M. A. Sharafeldin and G. Gróf, "Experimental investigation of flat plate solar collector using $\mathrm{CeO}_{2}$-water nanofluid," Energy Convers. Manag., vol. 155, pp. 32-41, 2018. 
[21] J. V. Kumar, A. Amarkarthik, R. Harish, S. Mugundan, and R. R. Suriyaa, "Performance Analysis of FlatPlate Solar Collector Using Tungsten Trioxide Nanofluid," in Advances in Materials Research, Springer, 2021, pp. 831-840.

[22] O. A. Alawi, H. M. Kamar, H. A. Mohammed, A. R. Mallah, and O. A. Hussein, "Energy efficiency of a flatplate solar collector using thermally treated graphene-based nanofluids: Experimental study," Nanomater. Nanotechnol., vol. 10, p. 1847980420964618, 2020.

[23] O. M. Hamdoon, "Improving the Performance of A Flat Plate Solar Collector Using Nanofluid as Working Fluid," Al-Rafidain Eng. J., vol. 25, no. 2, pp. 37-45, 2020.

[24] L. S. Sundar, E. V. Ramana, Z. Said, V. Punnaiah, K. V. V. C. Mouli, and A. C. M. Sousa, "Properties, heat transfer, energy efficiency and environmental emissions analysis of flat plate solar collector using nanodiamond nanofluids," Diam. Relat. Mater., vol. 110, p. 108115, 2020.

[25] O. A. Alawi et al., "Experimental and Theoretical Analysis of Energy Efficiency in a Flat Plate Solar Collector Using Monolayer Graphene Nanofluids," Sustainability, vol. 13, no. 10, p. 5416, 2021.

[26] L. H. Kumar, S. N. Kazi, H. H. Masjuki, M. N. M. Zubir, A. Jahan, and C. Bhinitha, "Energy, exergy and economic analysis of liquid flat-plate solar collector using green covalent functionalized graphene nanoplatelets," Appl. Therm. Eng., vol. 192, p. 116916, 2021.

[27] M. B. Nejad, H. A. Mohammed, O. Sadeghi, and S. A. Zubeer, "Influence of nanofluids on the efficiency of Flat-Plate Solar Collectors (FPSC)," in E3S Web of Conferences, 2017, vol. 22, p. 123.

[28] E. Arlikan, S. Abbasoluglu, and M. Gazi, "Experimental performance analysis of flat plate solar collectors using different nanofluids," Sustainability, vol. 10, no. 6, p. 1794, 2018.

[29] Y. Tong, X. Chi, W. Kang, and H. Cho, "Comparative investigation of efficiency sensitivity in a flat plate solar collector according to nanofluids," Appl. Therm. Eng., vol. 174, p. 115346, 2020.

[30] M. S. Gad, M. Said, and A. Y. Hassan, "Effect of different nanofluids on performance analysis of flat plate solar collector," J. Dispers. Sci. Technol., pp. 1-12, 2021.

[31] A. A. Hawwash, M. Ahamed, S. A. Nada, A. Radwan, and A. K. Abdel-Rahman, "Thermal Analysis of Flat Plate Solar Collector Using Different Nanofluids and Nanoparticles Percentages," IEEE Access, vol. 9, pp. 52053-52066, 2021.

[32] R. M. Mostafizur, M. G. Rasul, and M. N. Nabi, "Energy and Exergy Analyses of a Flat Plate Solar Collector Using Various Nanofluids: An Analytical Approach," Energies, vol. 14, no. 14, p. 4305, 2021.

[33] N. Akram et al., "Experimental investigations of the performance of a flat-plate solar collector using carbon and metal oxides based nanofluids," Energy, vol. 227, p. 120452, 2021.

[34] Q. He, S. Zeng, and S. Wang, "Experimental investigation on the efficiency of flat-plate solar collectors with nanofluids," Appl. Therm. Eng., vol. 88, pp. 165-171, 2015.

[35] A. M. Tomy, N. Ahammed, M. S. P. Subathra, and L. G. Asirvatham, "Analysing the performance of a flat plate solar collector with silver/water nanofluid using artificial neural network," Procedia Comput. Sci., vol. 93, pp. 33-40, 2016.

[36] S. K. Verma, A. K. Tiwari, S. Tiwari, and D. S. Chauhan, "Performance analysis of hybrid nanofluids in flat plate solar collector as an advanced working fluid," Sol. Energy, vol. 167, pp. 231-241, 2018.

[37] O. A. Hussein, K. Habib, A. S. Muhsan, R. Saidur, O. A. Alawi, and T. K. Ibrahim, "Thermal performance enhancement of a flat plate solar collector using hybrid nanofluid," Sol. Energy, vol. 204, pp. 208-222, 2020. 